\title{
THE DEVELOPMENT OF MARINE SPATIAL PLANNING AND ITS APPLICATION FOR FLOATING FISH NET CULTURE
}

\author{
D. Sutrisno ${ }^{a}$ \\ ${ }^{a}$ Geospatial Information Agency (BIG), Cibinong, Indonesia
}

Article Info:

Received: 3 October 2016

in revised form: 7 January 2017

Accepted: 20 February 2017

Available Online: 26 March 2017

\section{Keywords:}

Marine biodiversity, spatial planning, ecological and economic model, floating fish net culture

\section{Corresponding Author:}

Dewayany Sutrisno

Geospatial Information Agency (BIG), Cibinong, Indonesia

Email: dewayany@gmail.com

\begin{abstract}
Marine spatial planning has become the crucial issues for an archipelagic state such as Indonesia. The global market demand on marine economic species has been initiated the exploitation of the marine species which will become the hindrance in maintaining the sustainable marine biodiversity. Besides that, the degradation of marine species will also become the problem for traditional fishermen. Therefore, a model has to be employed to spatially manage the coastal waters as the alternative for fishermen activities during closed seasons, such as floating fish net culture. The aim of this study was to develop marine spatial planning model based on ecological approach in order to identify the potentiality of marine waters for marine culture such as floating fish net culture. The method for the model consisted of social assessment using the Delphi for developing the rule of marine planning for floating fish net culture and the spatial analysis technique for determining the model of marine spatial planning for floating fish net culture. The area of Kupang Bay waters, East Nusa Tenggara was used as the study area. The result indicated that the model can be used to sustainable marine spatial planning, especially for floating fish net culture. The model considered the aspects of potential area for marine culture, the management of zonation and transportation lanes, the conservation and protected area and the strategic area. Application in Kupang bay illustrated the aspect of technology input such as raceways since the majority of the area of Kupang Bay waters is classified as medium potential. Further research still needs to optimum the application of model to others marine area.
\end{abstract}

Copyright (C) 2017 GJGP-UNDIP This open access article is distributed under a Creative Commons Attribution (CC-BY-NC-SA) 4.0 International license.

How to cite (APA 6th Style):

Sutrisno, D. (2017). The development of marine spatial planning and its application for floating fish net culture. Geoplanning: Journal of Geomatics and Planning, 4(1), 41-52. doi:10.14710/geoplanning.4.1.41-52

\section{INTRODUCTION}

The development paradigm of fishery sub sector in Indonesia is currently focused on activities in captured fisheries of high economic species such as groupers, snappers etc. Groupers and snappers are types of demersal fish generally living in the coral reef environment. The sustainable potency of Indonesia marine fisheries resources reaches 6.4 million tons per year, including demersal fish and coral fish for 1.36 million and 145 thousand tons, respectively (Mukuan et al., 2014). The global market demand of the mentioned species has threaten the sustainability of the coral reef associated species, and equally to the coral reefs due to the usage of destructive fishing gears such as bomb or poison for exploitation by the fishermen are usually. Considering the sustainability of the capture fisheries prospect, especially for high economic fish species, the need to open access for capture fisheries activities to cultivation becomes crucial. Wide-ranging cultivating activities are possible since Indonesia is supported by coastal waters with many closed and semi-closed coastal areas with relatively calm water conditions. This condition is significantly prospective for the development of marine culture, such as floating fish net culture. The world-wide intensive culture of floating net cages is indicated as one of the major methods for intense fish production in the tropical areas (Liao et al., 2004; Ouattara et al., 2003). 
In Indonesia, the high economic fish product reaches only $15.45 \%$ of the floating fish net culture (Utama, 2008). This fact indicates the opportunity of floating fish net culture to improve the national product of high economic species such as groupers, snappers etc. However, the floating fish net culture deals with several problems, such as seedlings, capital, infrastructure, technological aspect, deleterious effects on the water quality and lack of integrated spatial planning of the coastal area (De Silva \& Phillips, 2007; Gorlach-Lira et al., 2013). Hence, marine spatial planning model should be beforehand used to determine the location of the floating fish net culture and its impact to the environment. The farmed fish are type of demersal fish such as groupers. This can simply be done if the model is developed based on ecological aspects (Oladokun et al., 2013).

There have been limited studies concerned on integrated spatial planning in coastal area. A few researchers focused on sea use management and marine fauna (Douvere, 2008; Douvere \& Ehler, 2009; Gilliland \& Laffoley, 2008; Hartoko \& Kangkan, 2009; Hegland, Raakjær, \& van Tatenhove, 2015; Murray \& Salama, 2016). Therefore, this research intends to develop the integrated marine spatial planning model. The aim of this study was to develop marine spatial planning model based on ecological approach to identify the potentiality of marine waters for marine culture specifically floating fish net culture.

\section{DATA AND METHODS}

\subsection{Study Area and General Method}

By taking into account the eastern part of Indonesia having clear water and high visibility, the coastal waters of Kupang Bay - East Nusa Tenggara Province was selected as the study area. Kupang Bay is located in the western part of Kupang city, the capital of East Nusa Tenggara Province. This bay has the blue clear water rich on biodiversity such as coral reefs and its associated fishes. Regarding the marine culture activities, the oyster pearl culture based on floating nets cages has been developed in the southern part of the area (Figure 1).

Figure 1. The Map of study Area (Modified from Google Earth)

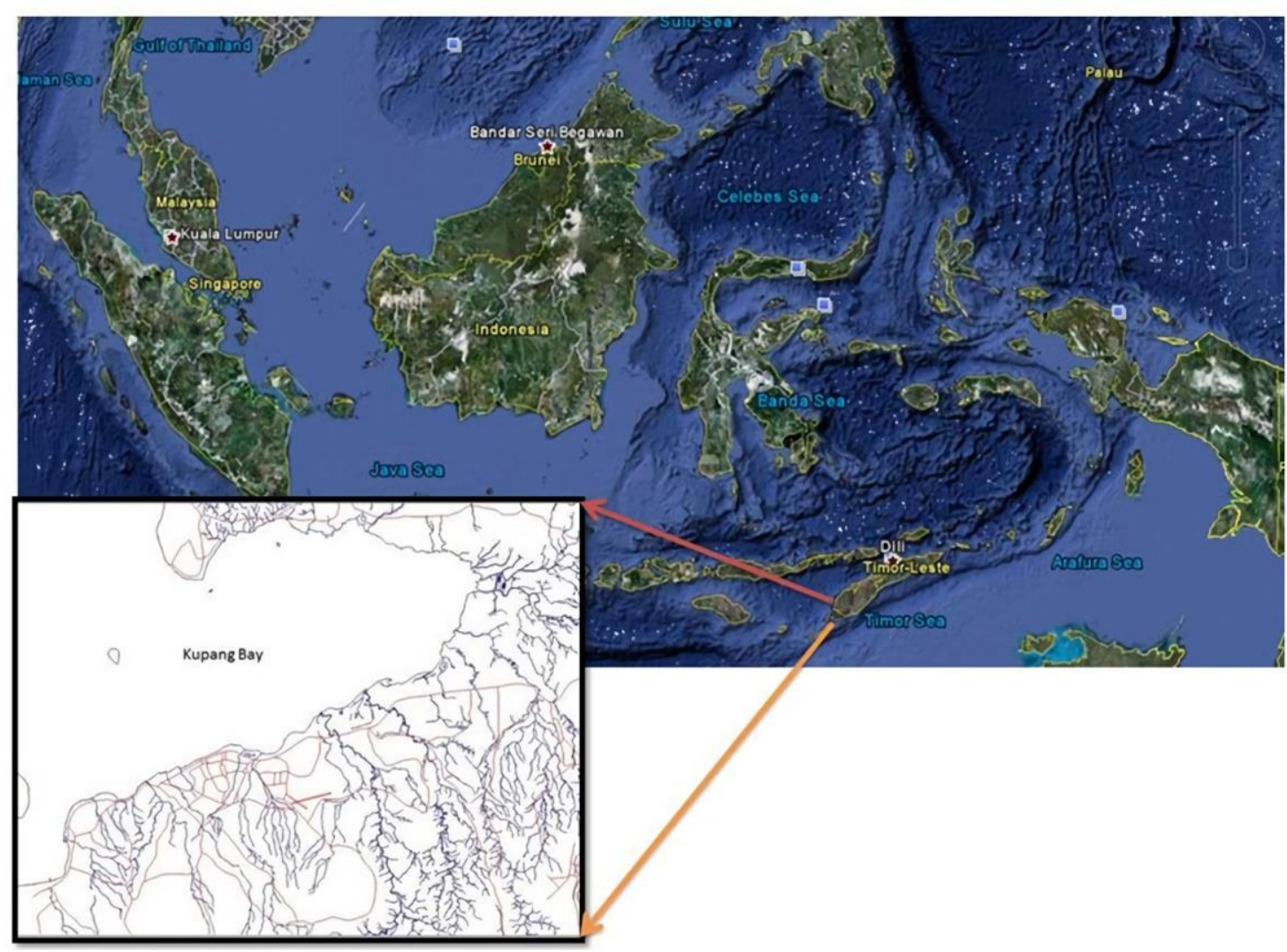


The method for developing the marine spatial planning model for floating fish net culture was based on the multi criteria analysis, which combine social assessment and technical spatial analysis. The social assessment consists of Delphi survey to identify the contributing parameters to the marine spatial planning for floating fish net culture model. Meanwhile, the technical spatial analysis consists of development of formula, scoring and weighting based on the result of social assessment and union overlay method. Taken together, these results will finally contribute to the development of marine spatial planning model. A literature review was done prior to the Delphi survey in order to obtain the most reliable opinion consensus on a group of experts on those parameters. The model should be developed based on ecological approach and sustainable marine spatial planning. The steps of developing the marine spatial planning for fish net culture were described in Figure 2.

Figure 2. Flowchart of the study

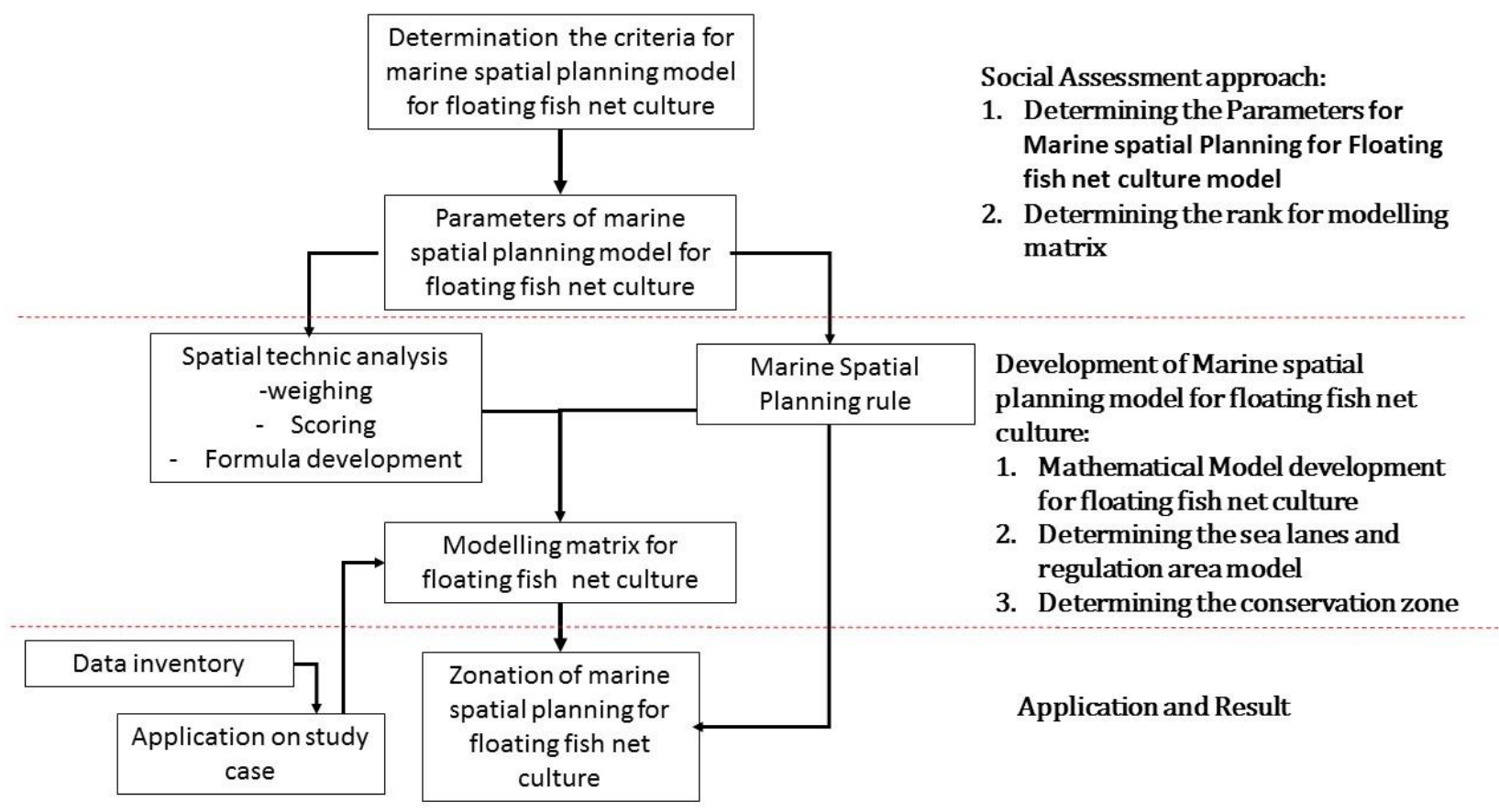

\subsection{Determining Marine Spatial Planning Model}

Assessing the relevant contributing parameters to a model is the important part to be completed prior the model development. In this case, a literature review collecting parameters carrying significant impacts on marine spatial planning for floating fish net culture has been carried out. The literature study should consider physical, chemical and biological characteristics of the water as well as technical aspects, infrastructure and environment for the best living environment of a marine species (Affan, 2012).

The Delphi method was used to select the parameters, the rank of parameters in each influence on sustainability marine species life and the rank for weighting and scoring of each parameter. Ten to fifteen marine management and spatial planning experts were participated in this survey as respondent. The method consisted of collecting each expert best opinion for the variables within a questionnaire and interview, coding the knowledge and the expert's evaluation on the knowledge based system (Rosnelly \& Utama, 2012). The survey was performed in three rounds. The first round aimed to identify the relevant parameters to the model. The second round aimed to rank the parameters due to the relevancy to achieve the optimal product. The third round aimed to rank the parameters for weighting and scoring (Figure 3). 
Figure 3. The Delphi Survey Steps

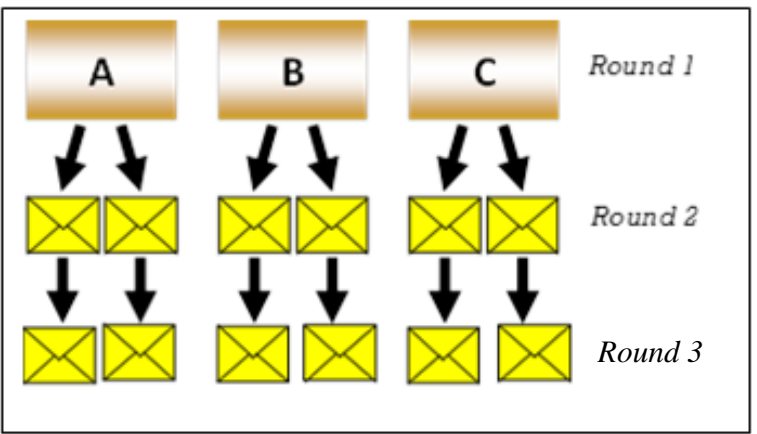

The weighting and scoring were carried out using Sutrisno (2006) concept that ranks the parameters into three requirement classes. (a) Minimum requirement parameters: The parameters should be existed to establish perpetuity life of the object (marine species) of marine culture. The absence of these parameters may result in the failure of the marine culture activities. (b) Optimal pre-requirement of marine culture objects: These parameters are the secondary requirement to have an optimum life of the marine culture objects. Some of water qualities parameters may be included in this requirement. (c) Ideal/ supporting requirement of marine culture objects: These parameters need to be existed for the better product of the marine culture. Some water quality parameters such as phosphate and $\mathrm{pH}$, security, distance marketing may become part of these aspects. The result of this step is the potential matrix for the marine spatial planning focusing on floating fish net culture.

The result of the delphi analysis resulted in the eleven critical parameters to the spatial model of the floating fish net culture, i.e: Protection, Pollutant, Primary Productivity, Bathymetry, Sea Temperature, Salinity, Visibility, Seabed material, Dissolved oxygen, $\mathrm{pH}$, and Phosphate. Nothing like land area, the criteria of assessing the suitability of the coastal waters for marine culture are dependable to management instead of substrate. Therefore, the rank of the parameters within a matrix should follow the management approach classifying the parameters into minimum, optimum and supporting requirements and can be expressed as:

$$
f_{s_{x}}=f\left(s_{i-n}, p_{i-n}, l_{i-n}, i_{i-n}, z_{i}\right)
$$

Whereas marine spatial planning for floating fish net culture $\left(f_{s_{x}}\right)$ should be dependent on;

a. $s=$ supporting environment condition for marine culture, consist of $i-n$ parameters such as; relatively calm waters area and pollutant free area. (a) Relatively calm waters: Marine culture needs a closed or semi closed coastal area, a safety coastal area from the storm, wave, current and any natural destruction. The absence of this aspect may result in the destruction of the marine culture infrastructure. (b) Pollutant free area: The marine culture area should be free of polluted matters. The presence of this aspect may decrease the quantity and quality even the extinction of the object of marine culture. The pollutant data can be assessed from pollutant data (secondary data form other research), remote sensing analysis that indicates extreme sedimentation, oil spill and eutrophication or through the distance from the residential, river mouth, port, fabrics or others nearby.

b. $\quad p=$ primary healthy living environment for the cultured, consist of $i-n$ parameters such as clear water, primary productivity, water depth, etc. (a) Primary productivity: depending on the nature feeding, the primary productivity has to be considered as important since it may affect the mortality of the species' object of the culture. (b) Clear water: The clearer the water, the healthier the environment available for marine culture. The clear water is indicated by the depth of visibility up to the bottom of the sea. (c) Depth: This aspect was importance due to the feeding and feces aspects. Because less depth may cause pollution from feeding activities as well as nearby area and even from the seabed itself.

c. $\quad I=$ Supporting living environment for culture consist of $i-n$ parameters such as water quality. 
d. $i=$ Supporting facilities and infrastructure consist of $i-n$ parameters such as transportation lanes, cold storage, and other infrastructure

e. $z$ = Determining national management zone for regency or province at $i$ mile from coastal based point.

$\left(S_{i-n}\right),\left(p_{i-n}\right), I$ and $z$ may be considered as minimum requirement parameters, $\left(I_{i-n}\right)$ as optimum or supporting requirement parameters. Thus following the above rule, the rank of parameters for developing the potential waters for floating fish net culture simply consider point $(a)$ to $(c)$, while points $(d)$ and $(e)$ are required for the whole model of marine spatial planning approach (Table 1). The parameters are;

a. Minimum requirement parameters

- Protected area, such as bay, strait and other protected area. The spatial data of these parameters can be obtained from remote sensing and base map analysis.

- Pollution: Under the assumption that no chemical pollutant exists in the area, the distance from ports, residential, river mouth and industrial areas can be assumed as the criteria for pollutant free and environmental management approach.

- Primary productivity: Under the assumption that the feedings depend more on the nature, the primary productivity can be represented by the spatial chlorophyll distribution. In this study, the primary productivity was obtained from BIG.

- Water depth: need to support the floating net infrastructure and sustainability of environmental. For this study, the water depth data was obtained from coastal environmental map (LPI) BIG. The mapping of water depth using remote sensing data has its limitation since either Landsat TM, Landsat 8 Olie or SPOT 6 were simply able to map 18 to 25 meter of water depth (Arief et al., 2013; Setiawan, Osawa, \& Nuarsa, 2014). Therefore, the bathymetry data from LPI map is more applicable.

- Sea temperature: The life span of specific species depends on the sea water temperature. Accordingly, the spatial information of sea surface temperature is important for developing the model.

- Salinity: maintaining the degree of water salinity is important for specific culture to be species. The fresh water impact may cause mortality as well as more saline water.

- Nearby land use system: these parameters may affect the marine culture area due to the pollution or introduction of destructive objects such as diseases or germs. Therefore, the development of the model essentially requires the land use information.

b. Optimal pre-requirement of marine culture objects: visibility and seabed material.

c. Ideal/ supporting requirement of marine culture objects: phosphate and $\mathrm{pH}$ may become part of these aspects. The data can be obtained from field observation

Table 1. Modeling matrix of potential area for floating fish net culture

\begin{tabular}{|c|c|c|c|c|c|c|c|c|c|c|}
\hline \multirow[t]{2}{*}{ No } & \multirow[t]{2}{*}{ Parameter } & \multirow{2}{*}{$\begin{array}{l}\text { Weighi } \\
\text { ng }\end{array}$} & \multicolumn{2}{|c|}{ P1 } & \multicolumn{2}{|c|}{ P2 } & \multicolumn{2}{|c|}{ P3 } & \multicolumn{2}{|c|}{$\mathbf{N}$} \\
\hline & & & Class & Score & Class & Score & Class & Score & Class & Score \\
\hline 1 & Protection & 10 & Bay & 18 & strait & 14 & $\begin{array}{l}\text { Cape } \\
\text { inside } \\
\text { strait }\end{array}$ & 10 & Open sea & 2 \\
\hline 2 & Pollutant & 10 & None & 18 & None & 14 & $\begin{array}{l}\text { Small } \\
\text { polluted }\end{array}$ & 10 & $\begin{array}{l}\text { Higly } \\
\text { poluuted }\end{array}$ & 2 \\
\hline 3 & $\begin{array}{l}\text { Primary } \\
\text { Productivity }\end{array}$ & 10 & $>500$ & 16 & $350-500$ & 14 & $250-350$ & 10 & $<250$ & 2 \\
\hline 4 & Bathymetry & 10 & $10-30$ & 16 & $30-50$ & 14 & $>50$ & 10 & $<10$ & 2 \\
\hline 5 & Sea Temperature & 10 & $28-29$ & 16 & $\begin{array}{l}27-28 \\
29-30\end{array}$ & 12 & $\begin{array}{l}25-27 \\
30-32\end{array}$ & 10 & $<25,>33$ & 2 \\
\hline 6 & Salinity & 10 & $>33$ & 16 & $31-33$ & 12 & $29-31$ & 10 & $<29$ & 2 \\
\hline 7 & Visibility & 8 & $>25$ & 14 & $10-25$ & 12 & $5-10$ & 10 & 0 & 2 \\
\hline 8 & Seabed material & 8 & $\begin{array}{l}\text { reef, } \\
\text { sand }\end{array}$ & 14 & sand & 12 & $\begin{array}{l}\text { Sandy } \\
\text { clay }\end{array}$ & 10 & muddy & 2 \\
\hline 9 & Dissolved oxygen & 6 & $7-8$ & 12 & $6-7,>8$ & 10 & $5-6$ & 8 & $<5$ & 2 \\
\hline 10 & $\mathrm{pH}$ & 6 & $7-8$ & 12 & $6-7,>8$ & 10 & $5-6$ & 8 & $<5$ & 2 \\
\hline 11 & Phosphate & 6 & $<0.4$ & 12 & $0.4-0.6$ & 8 & $5-6$ & 6 & $<5$ & 2 \\
\hline
\end{tabular}


The result of the survey states the weighting criteria assessed based on the scale of 1 to 10 , whereas the highest value is ten (10) and the lowest value is two (2). Meanwhile, the scoring method was assessed based on the scale of 1 to 20, whereas the highest value is twenty and the lowest values are two (2). The above matrix model modified the Bakosurtanal (2009), a suitability model to a potential area for floating fish net model, as shown as:

$$
P_{1-i}=\frac{\left(B o b_{\text {score }-1} * B o b_{\text {Par }-1}\right)+. .+\left(B o b_{\text {score }-n} * B o b_{\text {par }-n}\right)}{2}
$$

Whereas $P_{1-i}$ is the potential area classes 1 to $\mathrm{i}, B o b_{\text {score }}$ is the weighed parameters, $B o b_{\text {par }}$ is the scored for each parameters, $i$ - $n$ are the parameters for floating fish net model. So, the potential classes (P1 to N) can be classified as:

$\mathrm{P} 1$ if weighting scored is $\geq a$

$\mathrm{P} 2$ if else weighting scored is among $b-a$

$\mathrm{P} 3$ if weighting scored is among $c-b$

and $\mathrm{N}$ or not any if weighting scored is $\leq c$

Whereas and $a=1300, b=1026$ and $c=540$, those were calculated from the potential matrix.

\subsection{Mathematical Model Development}

\section{a. Determining the potential area for floating fish net sub-model}

The mathematical model for determining spatial prospect for floating fish net culture was modified from Bakosurtanal (2009). Bakosurtanal model is a suitability model for floating fish net culture. Meanwhile, this study developed the potential model for floating fish net culture. The parameters for Bakosurtanal model are only water qualities, while this model employed environment and marine regulations on spatial planning. The Bakosurtanal model is explained as:

$$
B o b_{\text {score }}=\frac{\left(B o b_{k e s-1} * B o b_{p a r-1}\right)+\left(B o b_{k e s-n} * B o b_{p a r-n}\right)}{B o b_{p a r-1}+B o b_{p a r-n}}
$$

Whereas Bob score is the suitability of coastal waters for floating fish net culture, Bob kes is the suitability weight, $B o b_{p a r}$ is the scored for each parameters, $i-n$ are the parameters for floating fish net model. The output of the model is classified into four classes according to its potential for floating fish net culture, there is high potential $\left(P_{1}\right)$, moderately potential $\left(P_{2}\right)$, low potential $\left(P_{3}\right)$ and not having any potential $(N)$. Union overlay method were employed for the implementation of the model, while the query was using the mathematical model of potential area for floating fish net culture.

\section{b. Determining The Sea Lanes Area and Regulation sub-model}

Regulation on zonation and transportation lanes are the crucial issues that should be implemented in marine culture management as it is stated in the law No 1/2014 regarding the zonation for marine spatial planning. The marine spatial planning should act upon the rule of management zone, such as located four or twelve miles from the coastline based on lowest water level (LWL) as well as the transportation lanes. The sub-model simply excluded the management zone and transportation lanes from potential area for floating fish net sub-model and explained as:

$$
F s=B o b_{\text {score }}-i_{i-n}+Z_{i}
$$

Whereas, $F_{S}$ is the floating fish net culture on zonation and lanes rules, Bob score is the potential area for floating fish net culture, $i-n$ are the transportation lanes and other infrastructure and $Z$ is the national management zonation at $i$ miles from coastal based points. Union overlay method were employed for this steps of assessment while the query was using the mathematical model of floating fish net culture on zonation and lanes rules 


\section{c. Analyzing the conservation zone}

Implementation of the floating fish net culture should consider its aspect to the environment. These criteria have been embedded in the model matrix but quite often ignoring the coastal or upland land utilization. For the best result of the floating fish net culture, the coastal waters area must be free from the influences of ports, dense population, industries, intensive agriculture and the river mouth related to upstream activities. Indeed, the numbers or the density of floating fish net per $\mathrm{km}$ square and distance from conservation or unique coastal ecosystem has also become part of conservation area assessment. Not any mathematical model was developed for this sub-model due to the complicated objects. Union overlay method was employed for this sub-model, following by query for ignoring the potential floating fish net culture area from nearby sensitive environment.

\subsection{Data Sources}

For the application of the model, the secondary spatial data were collected based on the requirement. These data were (a) base map from Geospatial Information Agency (BIG) (road, coast line, administrative boundary, river, annotation, and settlement); (b) water quality data such as dissolved oxygen, salinity, $\mathrm{pH}$, phosphate, pollutants, seabed material and primary productivity from BIG (c) secondary remote sensing derived data such as land use from BIG and (d) socio-economic data derived from district statistical agency (BPS, 2008) and coastal zone plan (Bappeda NTT, 2007).

\section{RESULTS AND DISCUSSION}

\subsection{Application of Floating Fish Net Culture Model}

Applying potential area for floating fish net model to the study area indicates that the majority of the waters in Kupang bay has medium prospect to be developed as floating fish net culture (Figure 4). The highest potential $(P 1)$ class individually covered the small area locates between the Semau Island the strait. This area has calm waters, free from pollutant, rich in primary productivity, and supported by suitable water depth, sea temperature and salinity. Meanwhile, the majority of the sea waters of Kupang bay were considered as the moderately potential area (P2). This class has limitation in Protection (current) and primary productivity. Since the primary productivity becomes the problem of these classes, the floating fish net planning should consider the intensive marine culture system that depends on nutritionally complete diet. The nutrition added to the system either fresh, wild, or form of dry pellet can be functional if the ecological aspect has been previously applied in the management system (Widiastuti, 2014). The small zone of low potential $(P 3)$ spreads nearby the coastal area indicat the depth problems beside primary productivity, protection and pollutant. Considering the depth, a vertical raceways culture system should be in consideration into the system since it has self-cleaning characteristic supported by medium to low current exchange rate (Beveridge, 2008; Black, 2001; Heard \& Martin, 1979). Related to the depth, the sedimentation from deforestation, industrial effluents are often associated with unsatisfactory quality of water (Chapman, 1996) that should be considered as well. The input to reduce the impact such as the net infrastructure is definitely needed.

The application of the model to the study area in Kupang bay was slightly different with Hartoko and Kangkan (2009). Hartoko and Kangkan (2009) assessed the Kupang Bay coastal waters resulting into two classes' i.e Highly Suitable-S1 and Moderately Suitable-S2. The limiting factors were dissolved oxygen (DO), water current, depth, and type of bottom substrate (Hartoko \& Kangkan, 2009). Hartoko and Kangkan (2009) study differed with the study in this paper in the consideration of the suitability analysis developed using spatial interaction RGB model, a remote sensing raster model. As opposed, this study was developed based on potential/ prospect zone by considering management approach that not only considered the suitability, but correspondingly regulation, management and environment.

\subsection{The Sea Lanes Area and Zonation Regulation Model}

Sea lanes are assigned by the Law of The Republic of Indonesia No 1/2014 as important part of marine spatial planning (sub section 2.2-point $d$ and $e$ ). Related to the marine spatial planning model for Floating 
fish net culture, the model for sea lane and zonation should exclude the lanes and limit the culture within the administrative zone for floating fish net culture area. The model can be modified into:

$$
F s=P_{1-i}-\left(l_{1-n}+\left(A-Z_{i}\right)\right)
$$

Whereas, $F_{S}$ is the floating fish net culture on zonation and lanes rules, $P_{1-i}$ is the potential area for floating fish net culture classes 1 to $i, l$ is the transportation lanes and other infrastructure from $1-n, A$ is the distance of exposure for study area from coastal points and $Z$ is the national management zonation at $i$ miles from coastal based points. Within the study area, there are two commercial ports, i.e. Tenau and balok, and Fisheries port namely as Oeba that should not include in the model.

Figure 4. Floating fish net prospect spatial data (Own Analysis, 2016)
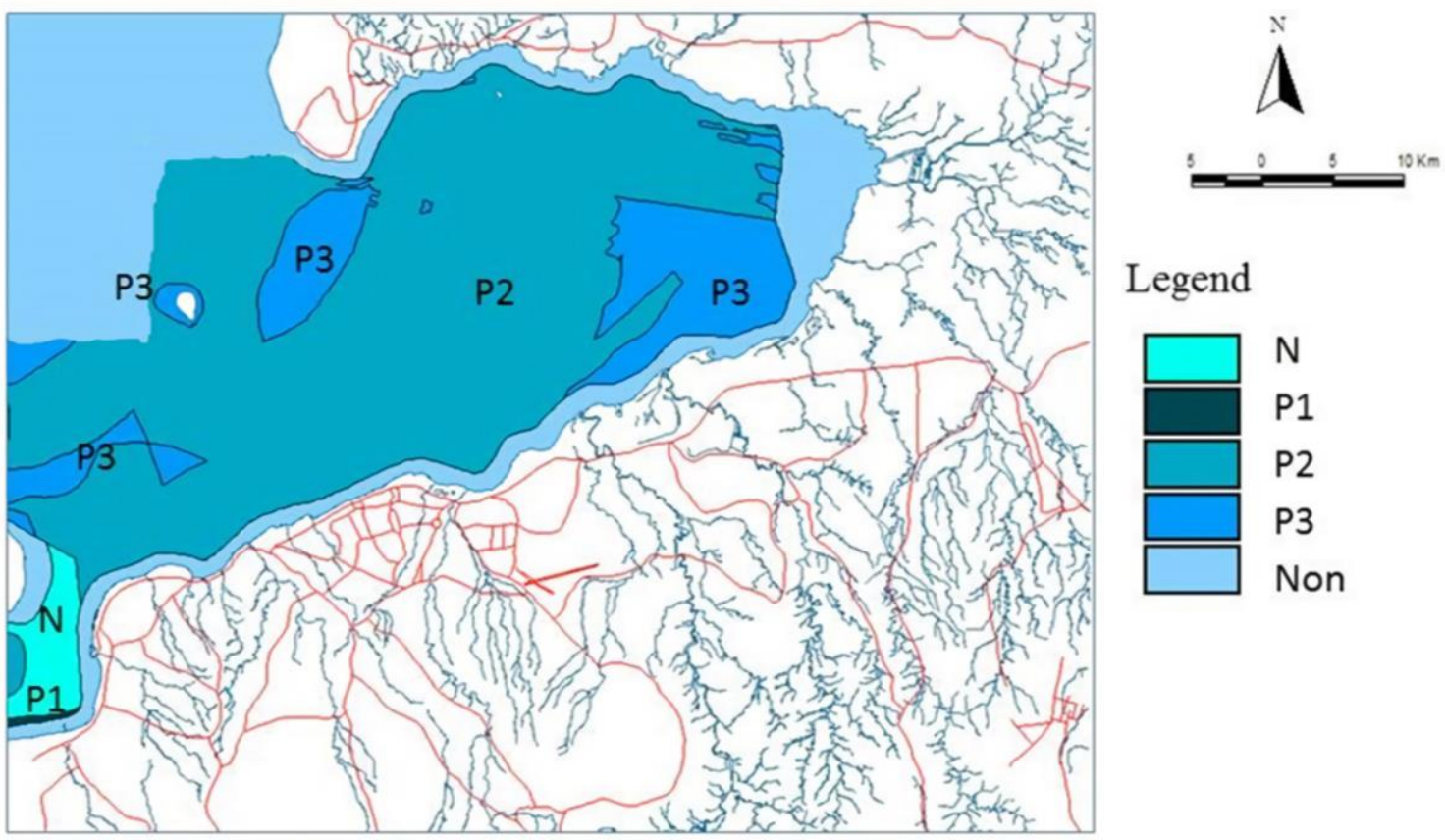

Legend

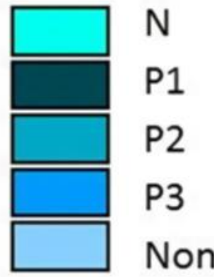

\subsection{Analyze of The Conservation Zone}

The environment assessment indicates the potential zone for floating net culture having minor problems regarding the environment condition. Marine spatial planning assigning the conservation area should be part of the planning (Law No 4/2014). It means that these areas should not be included in the spatial planning for floating fish net culture area. Therefore, the development of the culture should consider the distance from social economic activity and protected marine resources such as distance from the coral reefs area, ports, rivers and residential area (Figure 5). Applying these criteria to the marine spatial planning model for Floating fish net culture can be seen in Figure 6.

In general, implementation of the model illustrates the less area available for floating fish net culture within the Kupang Bay. Marine spatial planning considers the marine culture, conservation, national strategic, and lanes areas as it has been explored in this study. In the case of Kupang bay, two classes (P2 and P3) were defined to the development of the floating fish net culture. It means, more technology input is needed for developing the floating fish net culture. In this case due to the limitation in depth, primary productivity, protection and pollutant.

Considering the numbers or the density of floating fish nets per $\mathrm{km}$ square and its relation to the sustainable product and environment is the critical object to discuss, especially in detail marine spatial planning considering the detail information of in site planning. The intensive floating fish net culture can lead to the eutrophication of water bodies and to the emergence of deleterious effects on the water 
quality, such as the blooms of toxic cyanobacteria harmful for wildlife and humans (Gorlach-Lira et al., 2013). There are several works on the effect of fish culture in cages on water quality (see Jahani et al., 2012; Mente et al., 2006; Ntengwe \& Edema, 2008; Price et al., 2015; Price \& Morris Jr, 2013; Schenone, Vackova, \& Cirelli, 2011; Wu, 1995; Yin, Harrison, \& Black, 2008). Therefore, the waters can be divided into single kilometers square sea boxes $\left(1 \mathrm{~km}^{2}\right)$ not including the transportation lanes. For marine culture, less than $40 \%$ of the potential area can be developed as the floating fish net culture if the water area is designed for marine culture purposes. This limitation hopefully will decline the pollutant or disturbance to the environment. However, these numbers should be further analyzed since there is not any exact carrying capacities model to define the sea boxes concept in marine spatial planning.

Figure 5. (a) Coral reefs condition and (b) environment consideration (Own Analysis, 2016)


\section{Legend

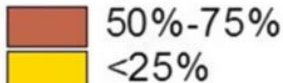

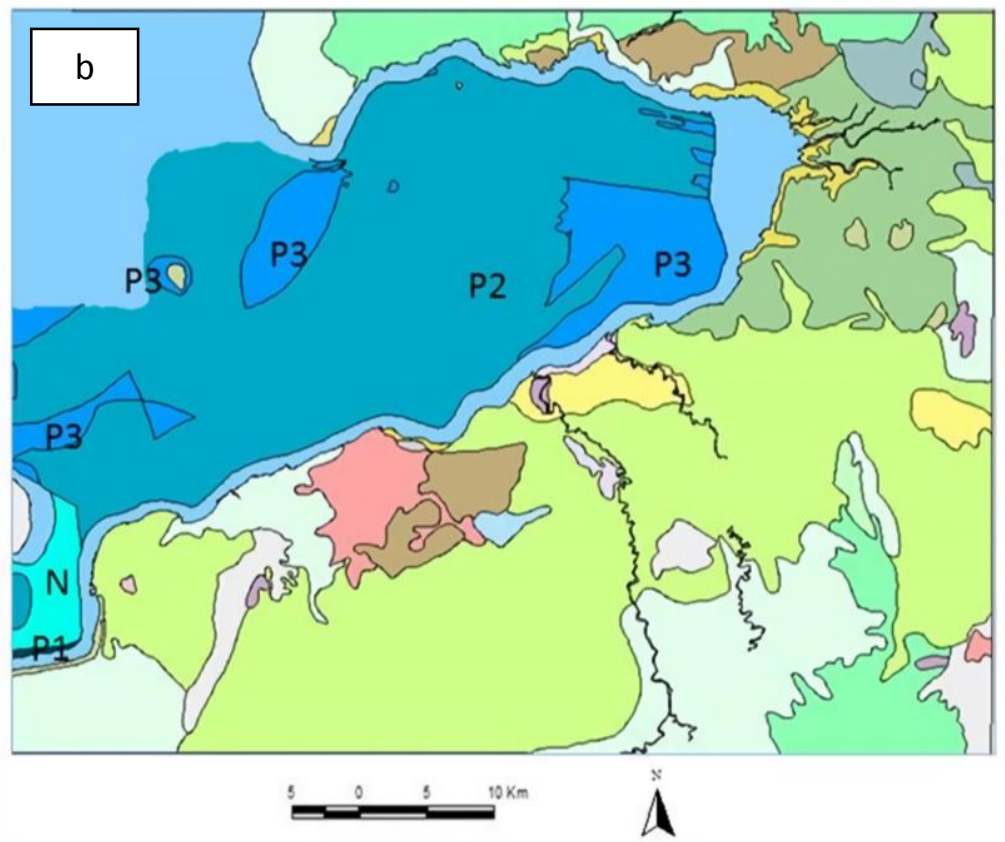

No data

Densed Forest

Sea

Bareland

Port

Town/ Villages

City

Streams

Shrub

Industrial area

Mangrove

Forest

Mix garden

Coconut

Airport

Bareland

Savana

Paddy Fields

Bush

Shrub + Bush

Densed Bush

Ponds

Fields

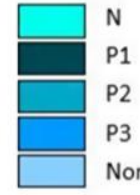


Figure 6. Enable Areas for Marine Spatial Planning for Floating Fish Net Culture (Own Analysis, 2016)

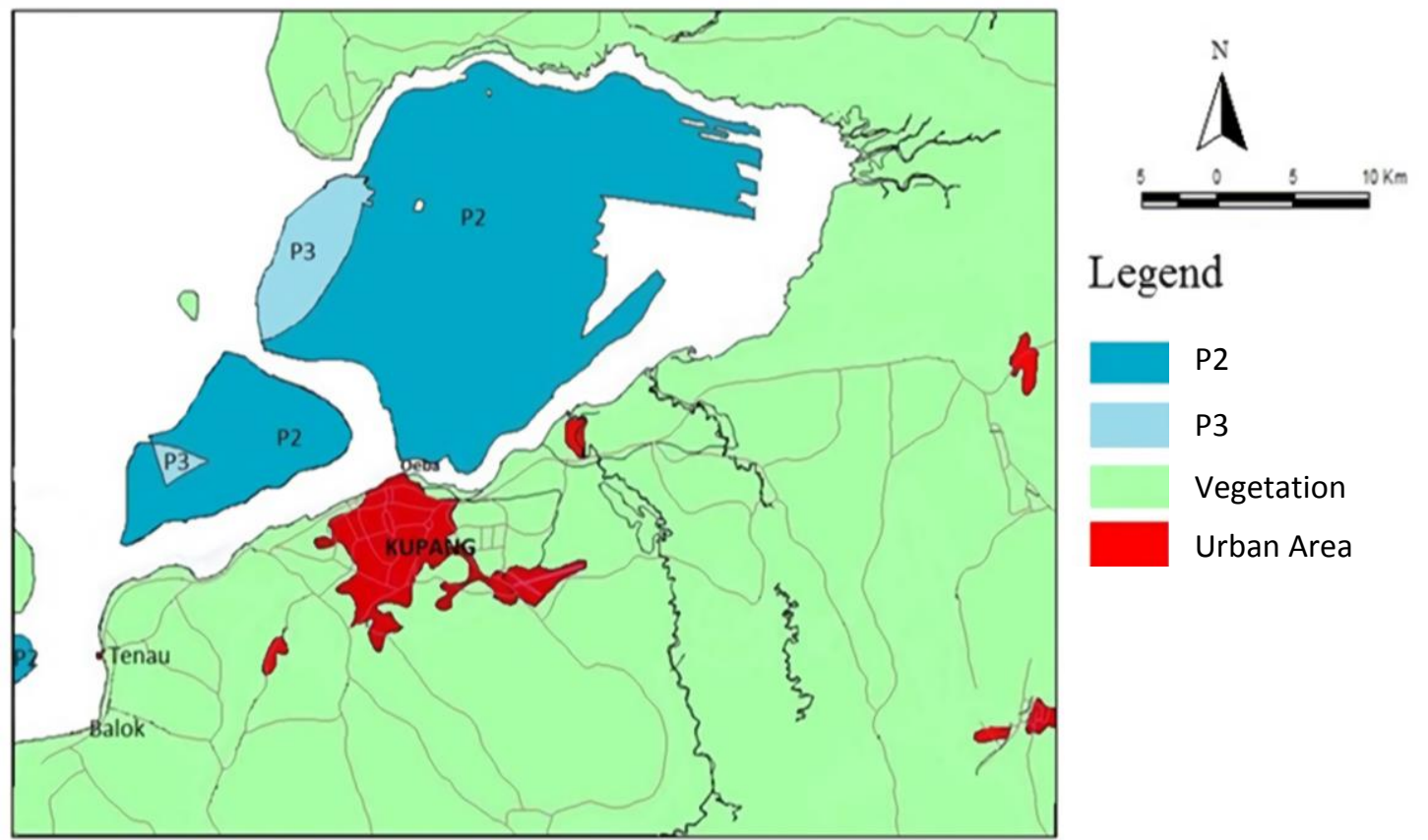

\section{CONCLUSION}

Marine spatial planning is the most important part of policy for obtaining sustainable marine development. The model of marine spatial planning for floating fish net culture has followed this policy . The model was developed based on management approach considering the potential area for marine culture, in this case for floating fish net culture, the zonation management and lanes, the conservation and protective area and so does the strategic area.

The application of the model to the study area, Kupang bay waters, indicates that the majority of the area was generally classified as medium potential. Several technological inputs should be added to the system to achieve the optimum result of sustainable floating fish net culture. The technological input should consider the artificial feedings due to the problem of primary productivity, relocation the marine culture or development of infrastructure technology due to the pollutant or water depth such as vertical raceways. Besides that, the coastal waters problems were varied from one to other location. This condition may not change the model of potential area for floating fish net culture, the model of zonation and lanes management and the model of conservation. But will change the constants and the rank of parameters within the model matrix. Therefore, a further study considering other area should be implemented using this model.

\section{ACKNOWLEDGMENTS}

The author thanks to the Geospatial Information Agency that has provide us the base and thematic geospatial data information. The author thanks equally the Central Bureau of Statistics (BPS) and the regional governments that have provide the data for this study.

\section{REFERENCES}

Affan, J. M. (2012). Identifikasi lokasi untuk pengembangan budidaya keramba jaring apung (KJA) berdasarkan faktor lingkungan dan kualitas air di perairan pantai timur Bangka Tengah. DEPIK Jurnal IImu-IImu Perairan, Pesisir dan Perikanan, 1(1), 78-85.

Arief, M., et al. (2013). Pengembangan Metode Pendugaan Kedalaman Perairan Dangkal Menggunakan Data Satelit Spot-4 Studi Kasus: Teluk Ratai, Kabupaten Pesawaran (Methode Development For Shallow Water Depth Bathymetric Estimation Using Spot-4 Satellite Data, A Case Study: Ratai Bay, Pesawaran District). Jurnal Penginderaan Jauh dan Pengolahan Data Citra Digital, 10(1), 1-14. 
Bakosurtanal. (2009). Kajian Potensi Sumberdaya Pesisir Kabupaten Boalemo. Jakarta.

Bappeda NTT. (2007). Rencana Zonasi: Pengelolaan Wilayah Pesisir Provinsi Nusa Tenggara Timur.

Beveridge, M. C. M. (2008). Cage Aquaculture. Wiley. [Google Books]

Black, K. D. (2001). Environmental impacts of aquaculture. Sheffield Biological Sciences.

BPS. (2008). Kabupaten Gorontalo Utara dalam Angka 2008. BPS Gorontalo.

Chapman, E. D. (1996). Chapter 3 - Selection of water quality variables.

De Silva, S. S., \& Phillips, M. J. (2007). A review of cage aquaculture: Asia (excluding China). FAO Fisheries Technical Paper, 498, 21.

Douvere, F. (2008). The importance of marine spatial planning in advancing ecosystem-based sea use management. Marine Policy, 32(5), 762-771. [CrossRef]

Douvere, F., \& Ehler, C. N. (2009). New perspectives on sea use management: Initial findings from European experience with marine spatial planning. Journal of Environmental Management, 90(1), 77-88. [CrossRef]

Gilliland, P. M., \& Laffoley, D. (2008). Key elements and steps in the process of developing ecosystem-based marine spatial planning. Marine Policy, 32(5), 787-796. [CrossRef]

Gorlach-Lira, K., et al. (2013). The influence of fish culture in floating net cages on microbial indicators of water quality. Brazilian Journal of Biology, 73(3), 457-463.

Hartoko, A., \& Kangkan, A. L. (2009). Spatial modeling for mariculture site selection based on ecosystem parameters at Kupang Bay, East Nusa Tenggara, Indonesia. International Journal of Remote Sensing and Earth Sciences (IJReSES), 6(1), 57-64

Heard, W. R., \& Martin, R. M. (1979). Floating horizontal and vertical raceways used in freshwater and estuarine culture of juvenile salmon, Oncorhynchus spp. Marine Fisheries Review, 41(3), 18-23.

Hegland, T. J., Raakjær, J., \& van Tatenhove, J. (2015). Implementing ecosystem-based marine management as a process of regionalisation: Some lessons from the Baltic Sea. Ocean \& Coastal Management, 117, 14-22. [CrossRef]

Jahani, N., et al. (2012). The effect of marine fish cage culture on benthic communities using bopa index in ghazale creek. Iranian Journal of Fisheries Sciences, 11(1), 78-88.

Liao, I. C., et al. (2004). Cobia culture in Taiwan: current status and problems. Aquaculture, 237(1), 155165.

Mente, E., Pierce, G. J., Santos, M. B., \& Neofitou, C. (2006). Effect of feed and feeding in the culture of salmonids on the marine aquatic environment: a synthesis for European aquaculture. Aquaculture International, 14(5), 499-522. [CrossRef]

Mukuan, E. M. R., So, S., Arfiati, D., \& Ch. Kepel, R. (2014). Development Opportunity Of Floating Net Cage (Fnc) SystemTrevally (Caranx Spp.) Culture Business In Amurang District, South Minahasa Regency, North Sulawesi, Indonesia. IOSR Journal of Business and Management, 16(9), 44-49. [CrossRef]

Murray, A. G., \& Salama, N. K. G. (2016). A simple model of the role of area management in the control of sea lice. Ecological Modelling, 337, 39-47. [CrossRef]

Ntengwe, F. W., \& Edema, M. O. (2008). Physico-chemical and microbiological characteristics of water for fish production using small ponds. Physics and Chemistry of the Earth, Parts $A / B / C, 33(8-13), 701-$ 707. [CrossRef]

Oladokun, O. S., Nik, W. B. W., \& Kader, A. S. A. (2013). Study of properties of components for offshore aquaculture technology farming. Journal of Science and Engineering, 1(2), 155-161.

Ouattara, N. I., et al. (2003). Aquaculture potential of the black-chinned tilapia, Sarotherodon melanotheron (Cichlidae). Comparative study of the effect of stocking density on growth performance of landlocked and natural populations under cage culture conditions in Lake Ayame (Côte d'Ivoire). Aquaculture Research, 34(13), 1223-1229.

Price, C., et al. (2015). Marine cage culture and the environment: effects on water quality and primary production. Aquaculture Environment Interactions, 6(2), 151-174.

Price, C. S., \& Morris Jr, J. A. (2013). Marine cage culture and the environment: twenty-first century science informing a sustainable industry.

Rosnelly, R., \& Utama, U. P. (2012). Sistem Pakar: Konsep dan Teori. Penerbit Andi.

Schenone, N. F., Vackova, L., \& Cirelli, A. F. (2011). Fish-farming water quality and environmental concerns in Argentina: a regional approach. Aquaculture International, 19(5), 855-863. [CrossRef] 
Setiawan, K. T., Osawa, T., \& Nuarsa, I. W. (2014). Aplikasi algoritma Van Hengel dan Spitzer untuk ekstraksi informasi batimetri menggunakan data landsat. In Seminar Nasional Penginderaan Jauh (pp. 222230).

Sutrisno, D. (2006). Marine Spatial Planning Analysis. Research Report. IPB Bogor.

Utama, F. W. (2008). Analisis kelayakan usaha budidaya ikan kerapu macan di Pulau Panggang, Kabupaten Administratif Kepulauan Seribu, DKI Jakarta. PhD Thesis.

Widiastuti, I. (2014). Small-scale Freshwater Aquaculture Practices in Indonesia: An application of Sustainable Livelihood Approach to Nile Tilapia Farmer in West Sumatera. PhD Thesis. Kagoshima University.

$\mathrm{Wu}, \mathrm{R}$. S. S. (1995). The environmental impact of marine fish culture: Towards a sustainable future. Marine Pollution Bulletin, 31(4-12), 159-166. [CrossRef]

Yin, K., Harrison, P. J., \& Black, E. (2008). Risk Analysis of Coastal Aquaculture : Potential Effects on Algal Blooms. Assessment and Communication of Environmental Risks in Coastal Aquaculture, 76, 175-199. 